九州大学学術情報リポジトリ

Kyushu University Institutional Repository

\title{
TAXONOMIC STUDIES ON THE GENERA APOROPHLEBUS, EUMICROSOMA AND PLATYTELENOMUS OFJAPANANDKOREA (HYMENOPTERA, SCELIONIDAE, TELENOMINAE)
}

Ryu, Joon

Hirashima, Yoshihiro

https://doi.org/10.5109/2514

出版情報: ESAKIA. 28，pp.49-62，1989-03-03. Entomological Laboratory，Faculty of Agriculture， Kyushu University

バージョン:

権利関係 : 


\title{
TAXONOMIC STUDIES ON THE GENERA APOROPHLEBUS, EUMICROSOMA AND PLATYTELENOMUS OFJAPANANDKOREA (HYMENOPTERA, SCELIONIDAE, TELENOMINAE)"
}

\author{
JoOn $\mathrm{RYU}^{2)}$ and Yoshiniro HiRashima \\ Entomological Laboratory, Faculty of Agriculture, \\ Kyushu University, Fukuoka 812, Japan
}

\begin{abstract}
Aporophlebus, Eumicrosoma and Platytelenomus of the subfamily Telenominae of the family Scelionidae are reported from Japan and Korea. Four new species, Eumicrosoma paulum Ryu, Platytelenomus brevis Ryu, $P$. convexus Ryu and $P$. elongatus Ryu are described. The followings are new records: Eumicrosoma from Korea, Eumicrosoma phaeax (Nixon) from Japan and Korea, and Platytelenomus danubialis Szelenyi from Japan. Asolcus minor Watanabe is transferred to Aporophlebus and is recorded from Korea for the first time.
\end{abstract}

Genus Aporophlebus Kozlov, 1970

Type-species : Aporophlebus aporus Kozlov, 1970.

Aporophlebus Kozlov, 1970, Ent. Obozr., $49: 216$.

Eight species of Aporophlebus are known from the Palaearctic Region by Kozlov ; from USSR (1972), Western Europe (1970), Moldavia (1970), Mongolia (1972), Turkmenia (1972) and Tadzhikistan (1972). Information on the occurrence of Aporophlebus in Japan and Korea was given by Masner (1976). So far as we know, this genus is represented by one species, A. minor, in Japan and Korea, which parasitizes the eggs of the Plataspidae (Heteroptera).

This genus is characterized as follows :

Head often elongate particularly in buccal region. Frons and cheeks with longitudinal (often fan-like) keels or striae. Eyes with minute hairs. Antennae 11-segmented in female, 12 -segmented in male. Mesoscutum in posterior half with or without traces of notauli ; mesoscutum and scutellum convex, arched as seen from side, with sculpture. Postmarginal vein usually short, as long as stigma1 vein, rarely longer. First metasomal tergum often light colored, orange-yellow.

1) Contribution from the Entomological Laboratory, Faculty of Agriculture, Kyushu University, Fukuoka (Ser. 3, No. 291).

2) Present address : Tokoku Apt. 32-207, Tokokudong, Dancho-cu, Seoul. 


\section{Aporophlebus minor (Watanabe, 1954), comb. n.}

Asolcus minor Watanabe, 1954, Trans. Shikoku Ent. Soc., 4 : 20-21. Female and male.

This species is chiefly characterized by the longitudinally striated frons and cheeks, and the presence of notauli. The first metasomal tergum is reddish yellow.

In his original description, Watanabe (1954) described the second funicle segment as "distinctly shorter than the third funicle segment in female". However, according to our measurements, the second funicle segment is a little longer than the third funicle segment.

Female : Black. Antennae, legs and ovipositor honey yellow except for 4-segmented antenna1 club

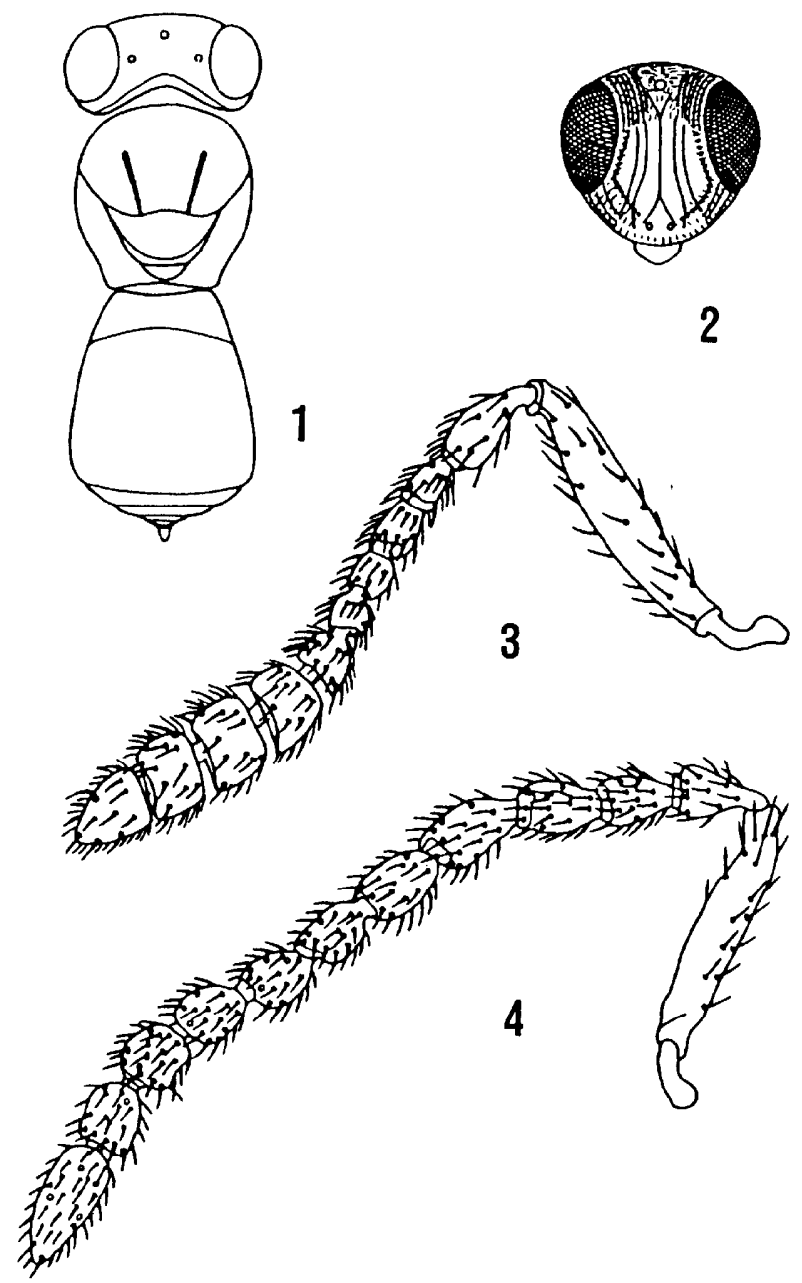

Figs. 1-4. Aporophlebus minor (Watanabe). 1: General habitus of female; 2 : Female head in front view ; 3 : Female antenna ; 4 : Male antenna. 


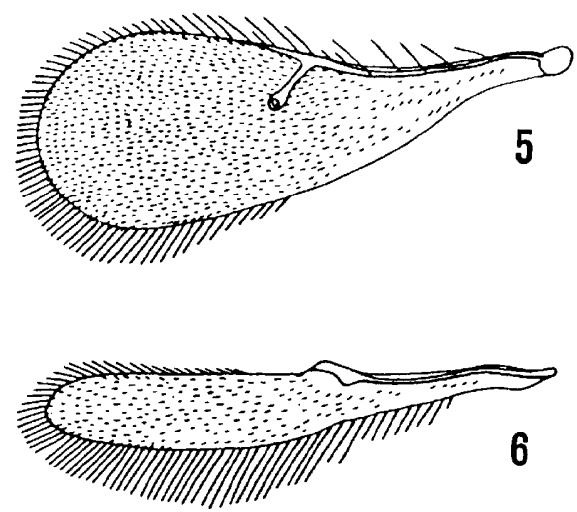

Figs. 5-6. Aporophlebus minor (Watanabe). 5 : Fore wing ; 6 : Hind wing.

which is brown. First metasomal tergum reddish yellow.

Head transverse as seen from above, about 2.7 times as broad as its median length and slightly broader than thorax $(9: 8)$; postero-lateral portions behind eyes very narrow, somewhat sharply ridged. Vertex rather broad, well convex, distinctly reticulate rugose, dull, with sparse, short, silvery hairs; the portion behind posterior ocelli rounded, not at all carinate. Frons longitudinally densely striated. Face broadly smooth and shining near antennae, with a median keel distinct below ; marginal keel of face very distinct, with a row of small punctures on inner side; this marginal keel bending to antenna1 toruli. Genae longitudinally distinctly striated, shining. Distance between eye and mandible rather long. Eyes with sparse minute hairs, appearing almost bare ; 1.3 times as long as broad ; interocular distance about as long as eye as seen in front. Posterior ocellar distance 1.5 times as long as lateral ocellar distance. Antennae 11-segmented ; scape 6 times as long as broad, 3 times as long as pedicel ; pedicel twice as long as broad, almost equal to next two segments combined ; first funicle segment 1.4 times as long as broad, a little shorter than secend; second 1.2 times as long as broad, 1.2 times as long as third ; third a little longer than broad, 1.3 times as long as fourth ; fourth quadrate, shorter than fifth $(5: 7)$; fifth slightly transverse $(6: 7):$ club 4 -segmented, proximal three segments subequal, transverse, and apical segment conical-ovate, 1.3 times as long as broad.

Thorax distinctly convex, a little longer than broad, shorter than metasoma $(6: 7)$; mesoscutum convex, with notauli on posterior $2 / 3$, closely reticulate-rugose, dull, covered with short silvery hairs ; scutellum large, well convex, with close sculpture as in mesoscutum, covered with short hairs ; metanotum very short, distinctly sculptured. Fore wings about 2.7 times as long as broad ; postmarginalis slightly longer than stigmalis $(5: 4)$; marginalis shorter than stigmalis $(3: 5)$. Hind wings about 6.6 times as long as broad; fringes about $4 / 5$ of the greatest width of hind wing.

Metasoma rather broad and slightly longer than broad $(9: 7)$; first tergum distinctly longitudinally costate; second tergum slightly transverse $(8: 9)$, longitudinally striated near apex in the median portion, somewhat obliterated laterally, elsewhere smooth and shining; following terga distinctly transverse; ovipositor slightly projected, about $1 / 3$ as long as metasoma.

Male : Similar to female, differing from it in the following characters : Antennae 12-segmented; scape 5.4 times as long as broad ; pedicel 1.7 times as long as broad, a little longer than first flagellar segment ; first, second and fourth equal in length and width, 1.4 times as long as broad ; third longest, about 1.3 times as long as second ; fifth to ninth almost equal in length and width, each segment 
oblong; apical segment conical, 2.4 times as long as broad.

Length : $0.75 \mathrm{~mm}$.

Host : Coptosoma punctissimum Montandon.

Specimens examined: JAPAN : 1 male, Yoshidani, Ojiya, Niigata Pref., Honshu, 8. viii. 1970 (K. Yamagishi) ; 5 females, Kamiozoegawa, Fuji, Saga Pref., Kyushu, 19. v. 1973 (K. Yamagishi) ;2 females, Kamiozoegawa, Fuji, Saga Pref., Kyushu, 13. iv. 1973 (K. Yamagishi); 4 females, Kamiozoegawa, Fuji, Saga Pref., Kyushu, 10. viii. 1973 (K. Yamagishi) ; 2 females, Kamiozoegawa, Fuji, Saga Pref., Kyushu, 6. ix. 1973 (K. Yamagishi) ; 4 females, Kamiozoegawa, Fuji, Saga Pref., Kyushu, 25. ix. 1973 (K. Yamagishi) ; 4 females, Kamiozoegawa, Fuji, Saga Pref., Kyushu, 9. x. 1973 (K. Yamagishi) ; 1 female, Kamiozoegawa, Fuji, Saga Pref., Kyushu, 25. x. 1973 (K. Yamagishi) ; 1 female, Miyanoura, Yakushima, Kagoshima Pref., Kyushu, 5-6. iv. 1971 (K. Yamagishi) ;1 female, Kurio, Yakushima, Kagoshima Pref., Kyushu, 1-4. iv. 1971 (K. Yamagishi). KOREA : 2 females, Mt. Sudo (700 m), Kyungsangpuk-do, Korea, 27. v. 1970 (K. Yamagishi); 1 females, Mt. Sudo (1,000 m), Kyungsangpuk-do, Korea, 30. v. 1970 (K. Yamagishi) ; 2 female, Mt. Sudo (700 m), Kyungsangpuk-do, Korea, 13-14. vii. 1970 (K. Yamagishi) ; 1 male, Mt. Sudo (400 m), Kyungsangpuk-do, Korea, 17-18. vii. 1971 (K. Yamagishi).

Distribution: Japan (Kyushu, Honshu, Shikoku) and Korea. This is the first record of this species from Korea.

Genus Eumicrosoma Gahan, 1913

Type-species : Eumicrosoma beneficum Gahan, 1913

Eumicrosoma Gahan, 1913, Proc. U. S. Natn. Mus., $46: 442$.

Baeoneurella Dodd, 1914, Trans. R. Soc. South Aust., 38 : 124.

Nardo Nixon, 1938, Ann. Mag. Nat. Hist., (11)1: 278.

Szelenyiella Szabo, 1957, Opusc. 2001. Bpest., 2 : 49-50.

The genus Eumicrosoma Gahan consists of 11 species in the world. It is known from Australian Region (North and South Queensland), Oriental Region (India), Neotropical Region (Brazil), Nearctic Region (West Indies) and Palaearctic Region (Europe, Ukreine). This genus was recorded from Japan by Masner (1976) but no specific name was indicated. The species of this genus parasitize the eggs of various bugs, Blissus leucopterus Say in N. America, Macropes excavatus Dist. in India, and Blissus pallipes in Japan. This genus is readily recognizable by the size very small, the thorax strongly dorsoventrally flattened and the metasoma often bright orange-yellow. Eumicrosoma is very similar to Platytelenomus in general appearance, but is distinguished by the venation of the fore wing (longer marginalis and shorter postmarginalis) and the number of antennal club (3-segmented, but 4-segmented in Platytelenomus).

In this paper two species, E. phaeax and E. paulum Ryu, sp. n. are treated. Both are recorded from Japan and one species, E. phaeax, is recorded from Korea for the first time. This is the first record of this genus from Korea.

Head transverse as seen from above, distinctly broader than long, slightly broader than thorax ; occiput not marginated (preoccipital carina absent), posterior ocelli close to inner orbit ; frons somewhat flattened, but subocular space bulging downwards. Antennae of female 11-segmented, of male 12-segmented; antenna1 club 3-segmented in female, male flagellar segments not transverse.

Thorax considerably flattened ; mesoscutum very flat, without notauli ; scutellum flat, trans- 
verse ; metanotum also flat ; propodeum short, truncate behind with a fine central groove. Fore wings narrow, marginal cilia very long ; stigmalis short, appearing as a continuation of marginalis ; marginalis very long, but shorter than submarginalis, extending beyond the middle of wings ; postmarginalis extremely short, less than half as long as stigmalis. Hind wings exceedingly narrow, parallel-sided beyond nervature.

Metasoma elliptical, not broader than thorax, very much flattened above ; first tergum broader than long; second tergum very long, almost extending to apex of metasoma ; apex of metasoma acute ; ovipositor concealed or extending less than one-fourth the length of metasoma.

\section{Key to Japanese Species (Females) of EumicRosoma}

1 (2) Mesoscutum nearly triangularly produced in front as seen from above ; antennae and legs pale honey yellow except for club; fore wing 7.8 times as long as broad, apical margin somewhat lanceolate; fringes of hind wing about 3 times as long as the greatest width of hind wing; length $1.0 \mathrm{~mm}$

phaeax (Nixon)

2 (1) Mesoscutum broadly rounded in front as seen from above ; frons broadly flat but a little more convex than in the preceding species ; antennae brownish throughout, legs yellowish brown ; length $0.9 \mathrm{~mm}$ paulum Ryu, sp. n.

\section{E umicrosoma phaeax (Nixon, 1938)}

Nardo phaeax Nixon, 1938, Ann. Mag. Nat. Hist., (11)1: 283. Female and male.

Eumicrosoma phaeax: Masner, 1965, Bull. Brit. Mus. Nat. Hist., 1 : 108.

This species may be characterized by the following points : Vertex very flat, deeply notched behind median portion and with a fine medial cleft ; frons flat and subocular space bulging downwards with fine reticulate sculpture ; thorax distinctly flattened above, mesoscutum nearly triangularly produced in front as seen from above ; metasoma orange-yellowish, elongate, about twice as long as
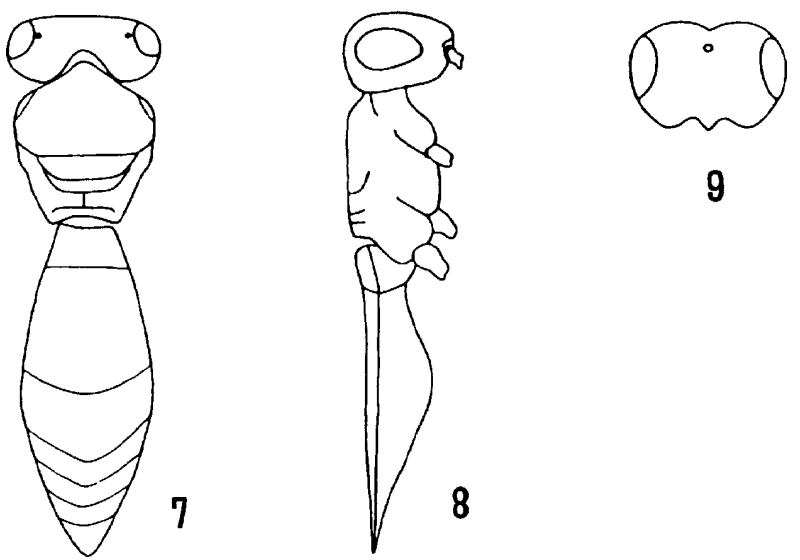

Figs. 7-9. Eumicrosoma phaeax (Nixon). 7 : General habitus of female ; 8 : Ditto, lateral view ; 9: Female head in front view. 

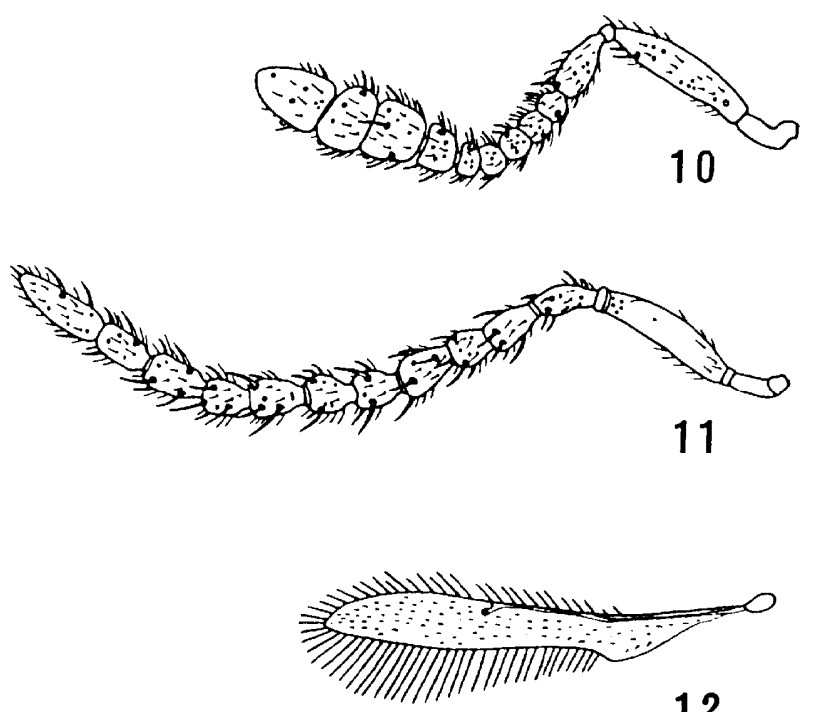

12

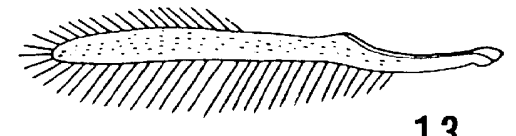

13

Figs. 10-13. Eumicrosoma phaeax (Nixon). 10 : Female antenna ; 11: Male antenna ; 12 : Fore wing ; 13 : Hind wing.

thorax and broadest nearly at the middle ; hind wing exceedingly narrow and its fringes about 3 times as long as width of the same wing.

The males of this species were bred from the eggs of a Hemipteron Blissus pallipes by $\mathbf{Y}$. Murakami (1956) for the first time.

Female : Antennae and legs pale honey-yellow except for 3-segmented club which is brown. Metasoma orange-yellow except for the median portion reddish brown.

Head markedly transverse as seen from above, more than 3 times as broad as its median length and a little broader than thorax (11: 9) ; head, as seen in front, with its upper and lower sides subparallel, Vertex very flat, finely reticulate-sculptured, deeply notched behind median portion and with a fine cleft which reaches nearly mid ocellus; the portion behind eye well developed. Frons, in greater part smooth and shining with scattered punctures ; subocular space bulging downwards, finely reticulate-sculptured as in vertex. Clypeus conically raised. Eyes bare, 1.3 times as long as broad ;interocular distance broad, 1.4 times as long as eye as seen in front. Antennae ll-segmented ; scape rather long, about 4 times as long as broad, almost equal to pedicel and three funicle segments combined ; pedicel about 1.7 times as long as broad; first to fourth funicle segments subequal, bead-like ; fifth and sixth a little transverse ; club 3-segmented, proximal first segment quadrate, a little longer than broad, second slightly transverse and apical segment conical-ovate, 1.3 times as long as broad.

Thorax distinctly flattened above and almost on a level with metasoma ; mesoscutum, as seen 
from above, nearly triangularly produced in front, in greater part smooth and shining with fine reticulate sculpture in antero-lateral portion ; scutellum semicircular, smooth and shining with fine punctures along the edge ; metanotum extremely transverse, glabrous ; propodeum rather long, nearly as long as scutellum, its surface smooth, but with some feeble punctures along the posterior margin, central groove very fine. Fore wings 7.3 times as long as broad, apical margin somewhat lanceolate ; stigmalis very short and submarginalis 1.8 times as long as marginalis. Hind wings exceedingly narrow, parallel-sided beyond the nervature ; fringes about 3 times as long as the greatest width of hind wing.

Metasoma elongate, 2.3 times as long as broad and about twice as long as thorax ; broadest nearly at the middle ; first tergum transverse, evenly costate all over ; second tergum with fine striae on its extreme base ; following terga very short with sparse hairs on lateral portions. Ovipositor clearly visible through the pale integument of metasoma.

Male : Legs pale yellow. Antennae dark brown, 12-segmented; pedicel nearly as long as first flagellar segment and each flagellar segment not transverse ; fifth to ninth subequal in length, distinctly longer than broad. Metasoma shorter and narrower than in female. Other characters like female.

Length: Male $0.9 \mathrm{~mm}$, female $1.0 \mathrm{~mm}$.

Host : Blissus pallipes (in Japan); Macropesexcavatus Distant (in India).

Specimens examined: JAPAN : 1 female, Mt. Inunaki, Fukuoka Pref., Kyushu, '24. vi. 1969 (0. Yata) ; 1 female, Chikuzen-Okinoshima, Fukuoka Pref., Kyushu, 25-28. vii. 1958 (Y. Hirashima et al.) ; 1 female, Betsukari, Mashike, Rumoi, Hokkaido, 20-23. viii. 1971 (K. Yamagishi) ;1 female, Kamiozoegawa, Fuji, Saga Pref., Kyushu, 10. viii. 1973 (K. Yamagishi) ; 3 males, bred from the eggs of Blissus pallipes, Hakozaki, Fukuoka, Kyushu, 25-29. vi. 1956 (Y. Murakami) ; 3 males, Kamiozoegawa, Fuji, Saga Pref., Kyushu, 4. vii. 1973 (K. Yamagishi). KOREA : 1 male, Mt. Yongmunsan, Kyunggi-do, 4. vii. 1982 (J. Ryu).

Distribution : Japan (Kyushu, Hokkaido), Korea and India. This is the first record of this species from Japan and Korea.

\section{Eumicrosoma paulum Ryu, sp. n.}

This new species is very similar to E. phaeax, but differs from the latter in having the mesoscutum broadly rounded in front as seen from above, antennae brownish throughout and vertex, subocular space and thorax more distinctly sculptured.

Female : Antennae brownish throughout. Legs yellowish brown. Metasoma reddish yellow except for the median portion dark brown.

Head distinctly transverse as seen from above, about 4 times as broad as its median length and nearly as boad as metasoma. Vertex rather flat, distinctly reticulate-sculptured with a fine medial cleft ; occiput behind median portion deeply notched. Frons broadly flat but a little more covex than in E. phaeax, with a row of punctures along inner orbit; subocular space bulging downwards with distinct reticulate sculpture. Clypeus conically raised, Eyes bare, 1.5 times as long as broad ; interocular distance about 1.3 times as long as eye. Antennae 11-segmented ; scape about 4 times as long as broad, 3 times as long as pedicel ; pedicel 1.3 times as long as broad, about twice as long as first funicle segment ; first to third subequal, bead-like ; fourth rounded, a little shorter than third ; fifth and sixth a little transverse ; club 3-segmented, proximal first segment a little longer than broad, second 


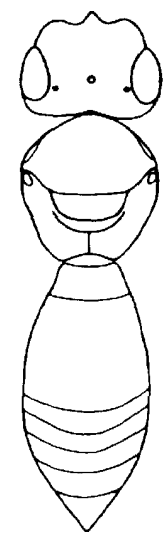

Fig. 14. Eumicrosoma paulum Ryu, sp. n. General habitus of female.

quadrate and apical segment conical ovate, 1.5 times as long as broad.

Thorax distinctly flattened above; mesoscutum broadly rounded in front as seen from above, distinctly reticulate sculptured in antero-lateral portion and elsewhere smooth and shining ; scutellum smooth and shining with some punctures along the posterior ridge ; metanotum very short, smooth and shining ; propodeum rather long, a little longer than scutellum, its surface smooth but with some sculpture along the postero-lateral portion and central groove very fine.

Metasoma elongate, 2.3 times as long as broad and about 1.9 times as long as thorax ; first tergum transverse, longitudinally costate all over ; second tergum basally striated ; following terga transverse.

Length : $0.9 \mathrm{~mm}$.

Type material : Holotype female (Type No. 2222, Kyushu Univ.), Mt. Kiso-komagatake, Nagano Pref., Honshu, 14. vii. 1967 (H. Taguchi).

Distribution: Japan (Honshu).

\section{Genus Platytelenomus Dodd, 1914}

Type-species : Platytelenomus planus Dodd, 1914.

Platytelenomus Dodd, 1914, Ent. News, '25 : 126.

The genus Platytelenomus Dodd has a wide distribution. Up to the present, 9 species have been described from Australia (Dodd, 1914 ; Kieffer, 1926), South Africa (Gahan, 1922), Sudan and Senegal (Nixon, 1935), Mauritius (Moutia et Courtois, 1952), Hungary (Szelenyi, 1939), Czechoslovakia (Masner, 1955, 1956) and the Soviet Union (Masner et Kozlov, 1965; Kozlov, 1970, 1973). This genus was recorded from Japan by Masner (1976) but no specific name was indicated. The species of this genus parasitizes the eggs of Lepidoptera belonging to the Noctuidae and Pyralidae.

In this paper, 4 species of Platytelenomus are treated. Three new species are described from Japan and Korea ; and 1 Palaearctic species is recorded from Japan for the first time.

Body strongly flattened. Vertex very thin. Eyes slightly pubescent. Antennae of female 11- 
segmented, club 4-segmented; antennae of male 12-segmented. Thorax longer than broad ;mesoscutum nearly as long as broad, without notauli ; scutellum short, semicircular, entirely smooth and shining ; metanotum very short ; propodeum rather long. Stigmalis longer than marginalis ; postmarginalis about twice as long as stigmalis. Second metasomal tergum longest.

\section{Key to Japanese and KoRean species (Females) of Platytelenomus}

1. Metasoma nearly as long as thorax, broad, broadest much beyond the middle, apex not sharply pointed ; head very thin, as seen from above, about 5.7 times as broad as its

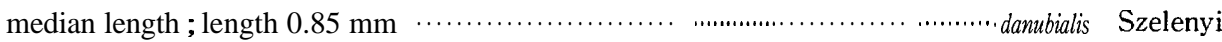

- Metasoma elongate, longer than head and thorax combined, apex sharply pointed …..............

2. Propodeum rather short, without a central groove, strongly sculptured ; head strongly transverse, as seen from above, about 3.8 times as broad as its median length ; length

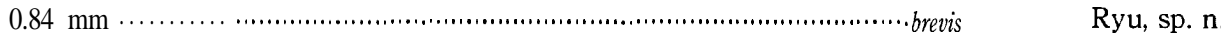

- Propodeum rather long, with a central groove, not strongly sculptured (portion lateral to the central groove nearly smooth)

3. Vertex, as seen in front, distinctly convex above ; femora black, tibiae infuscated ; length

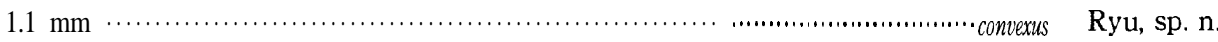

Vertex, as seen in front, not convex above, rather flat ; femora infuscated ; length $1 \mathrm{~mm}$ elongatus Ryu, sp. n.

\section{Platytelenomus danubialis Szelenyi}

Platytelenomus danubialis : Szelenyi, 1939, Ann. Hist. Nat. Mus. Hung., 32: 125-127. Female.

Plutytel enomus danubialis : Masner, 1955, Acta Ent. Mus. Nat., Pragae, $30: 137,139$.

Platytelenomus danubialis: Kononova, 1973, Ent. Obozr., 52 (3): 663. Female.

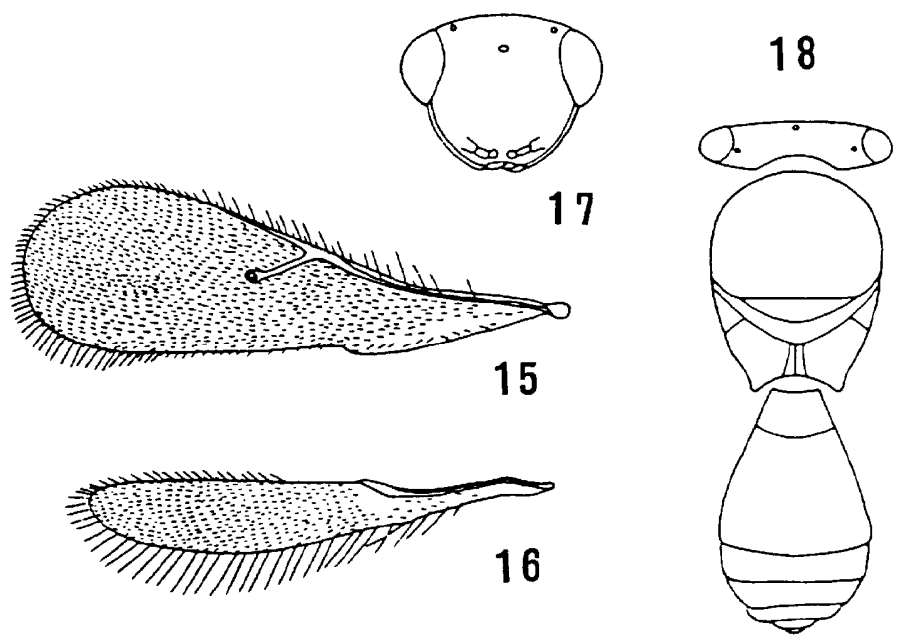

Figs. 15-18. Platytelonomus danubialis Szelenyi. 15 : Fore wing ; 16 : Hind wing ; 17 : Female head in front view ; 18 : General habitus of female. 
This species is characterized by the vertex very thin, frons and face distinctly flat, mesoscutum closely reticulate-sculptured, obliterated posteriorly, propodeum rather long with a fine central groove and punctures along the edge, and metasoma rather broad, broadest much beyond the middle, roundly truncated at apex.

Female: Brownish black. Antennae brownish with scape yellowish brown and club slightly darkened. Legs predominantly yellowish with femora light brown.

Head extremely transverse as seen from above, about 5.7 times as broad as its median length and slightly broader than thorax $(9: 8)$. Vertex very thin, finely granulate with short hairs. Frons and face distinctly flat, entirely smooth and shining. Eyes with extremely short hairs ; interocular distance rather broad, 1.5 times as long as eye. Antennae 11-segmented ; scape 3.4 times as long as broad, 2.4 times as long as pedicel ; pedicel 1.8 times as long as broad, 1.5 times as long as first funicle segment ; third and fourth quadrate; fifth transverse ; club 4-segmented, proximal four segments slightly transverse and apical segment oblong, 1.3 times as long as broad.

Thorax distinctly flattened, slightly broader than abdomen (6:5); mesoscutum flat and broad, closely reticulate-sculptured, and obliterated posteriorly, smooth and shining and covered with short silvery hairs ; scutellum semicircular, entirely smooth and shining ; metanotum very short, smooth and shining; propodeum rather long, with a fine central groove and punctured along the edge. Fore wings 3 times as long as broad; postmarginalis 4 times as long as marginalis, 1.8 times as long as stigmalis. Hind wings 5.9 times as long as broad ; fringes as long as $2 / 3$ of the greatest width of hind wing.

Metasoma nearly as long as thorax, nearly 1.5 times as long as broad and broadest much beyond the middle ; first tergum transverse with longitudinal costae on basal half ; second tergum slightly transverse, 0.8 times as long as broad, with longitudinal, fine striae on basal $1 / 3$, elsewhere smooth and shining ; following terga transverse, abruptly truncated toward apex.

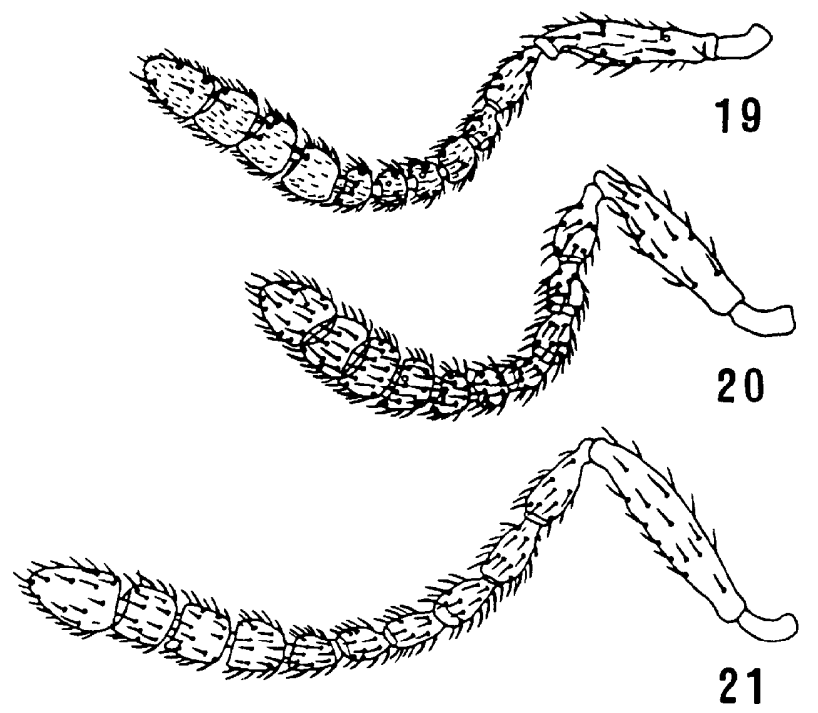

Figs. 19-21. Female antennae of Platytelenomus spp. 19 :P. danubialis Szelenyi ; 20 : P.brevis Ryu, sp. n. ; 21: P. convexus Ryu, sp. n. 
Length : $0.85 \mathrm{~mm}$.

Host :Sesamia cretica and Chilo pyrocaustalis (in CSR).

Specimens examined : JAPAN : 1 female, Kamiozoegawa, Fuji, Saga Pref., Kyushu, 5. vi. 1973 (K. Yamagishi) ; 1 female, Kamiozoegawa, Fuji, Saga Pref., Kyushu, 16. vi. 1973 (K. Yamagishi).

Distribution : Japan (Kyushu), USSR, CSR and Hungary. This is the first record of this species from Japan.

\section{Platytelenomus brevis Ryu, sp. n.}

This new species is similar to Platytelenomus elongatus Ryu, sp. n., but differs from the latter by having the metasoma distinctly concave posteriorly, the second metasomal tergum virtually unsculptured and the propodeum rather short, without central groove.

Female : Black. Antennae brown except for apex of pedicel which is yellowish brown. Legs brown except for trochanters and tarsi which are yellowish brown.

Head very strongly transverse as seen from above, about 3.8 times as broad as its median length and a little broader than thorax $(11: 10)$. Vertex very short, reticulate; the portions behind eyes well developed ; occiput notched. Frons rather flat, smooth and shiny. Eyes with short hairs, 1.6 times as long as broad ; interocular distance about 1.1 times as long as eye. Posterior ocellar distance about 1.9 times as long as lateral ocellar distance. Antennae ll-segmented ; scape 4 times as long as broad, 2.6 times as long as pedicel ; pedicel twice as long as broad, 1.4 times as long as first funicle segment ; first 1.4 times as long as broad, slightly longer than second ; second 1.2 times as long as broad, as long as third ; fourth as long as fifth, slightly transverse ( $8: 9)$; club 4-segmented, each segment slightly transverse except for apical segment which is 1.4 times as long as broad, conical-ovate.

Thorax distinctly flattened, longer than broad $(9: 7)$; mesoscutum with closely reticulate sculpture, obliterated posteriorly and covered with short silvery hairs ; scutellum transverse, entirely smooth and shining with fine punctures along the postero-lateral edge ; metanotum very short, about half as long as scutellum, smooth and shining; propodeum rather short, strongly sculptured. Fore wings 3 times as long as broad ; submarginalis 8 times as long as marginalis ; marginalis $3 / 7$ as long as stigmalis ; postmarginalis indistinct, but nearly twice as long as stigmalis. Hind wings 6.3 times as long as broad ; fringes as long as $5 / 7$ of the greatest width of hind wing.

Metasoma elongate, distinctly concave posteriorly, twice as long as broad and longer than thorax ( $7: 5)$; first tergum transverse, weakly costate on basal half ; second tergum about 1.2 times as long as broad, virtually unsculptured except for the extreme base; following terga distinctly transverse, sharply converging toward apex.

Length : approx. $0.84 \mathrm{~mm}$.

Typematerial: Holotype female (Type No. 2222-A, Kyushu Univ.), Mt. Katsuragi, Nara Pref., Honshu, 25. viii. 1969 (0. Yata).

Distribution : Japan (Honshu).

\section{Platytelenomus convexus Ryu, sp. n.}

This new species is similar to Platytelenomuselongatus Ryu, sp. $\mathrm{n}$. in the sculpture of the metasoma, but differs from the latter in having the vertex, as seen in front, distinctly convex above. This is further characterized by the eyes rather long, 1.8 times as long as broad, the interocular distance rather short, the metasoma elongate and the first metasomal tergum longitudinally costate all 

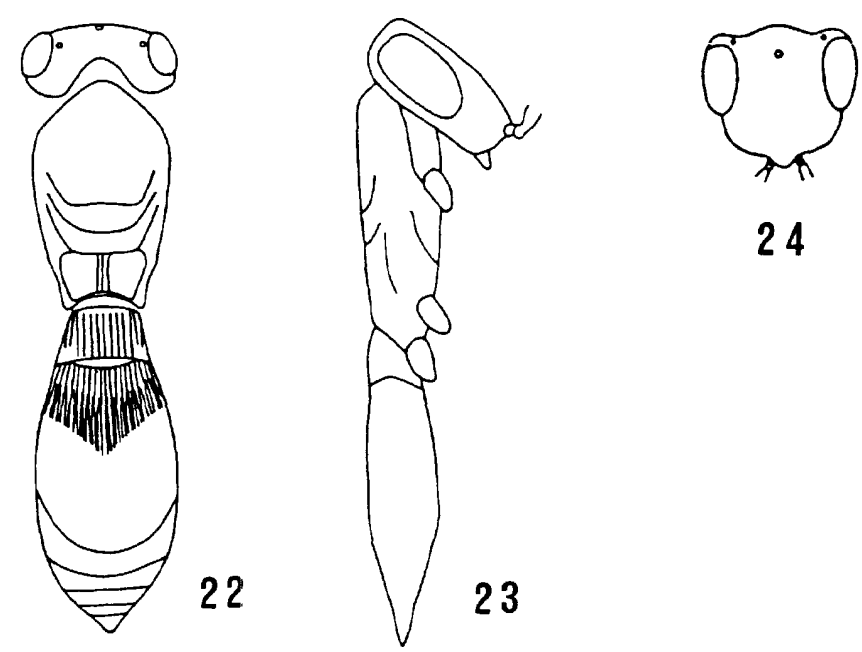

Figs. 22-24. Platytelenomus convexus Ryu, sp. n. 22 : General habitus of female ; '23 : Ditto, lateral view ; 24 : Female head in front view.

over.

Female : Black. Antennae brownish, with radicle black, scape and pedicel yellowish brown. Coxae and femora black, tibiae brownish black with apical portion yellowish and tarsi yellow with apical segments slightly darkened.

Head distinctly transverse as seen from above, about 4.2 times as broad as its median length and slightly broader than thorax $(9: 8)$. Vertex, as seen in front, distinctly convex medially with closely reticulate sculpture ; postero-lateral portions behind eyes rather well developed ; occiput deeply notched. Frons and face rather flat, smooth and shining ; subocular space microscopically sculptured. Eyes rather long, 1.8 times as long as broad ; interocular distance rather short, nearly as long as eye. Posterior ocellar distance 1.8 times as long as lateral ocellar distance. Antennae rather slender, 11segmented ; ratio of each segment as, $5.9: 2.3: 1.9: 1.9: 1.6: 1.3: 1.4: 1.5: 1.5: 1.5: 2.4$ in length, and $1.2: 1.0: 1.0: 0.9: 0.9: 1.0: 1.2: 1.5: 1.5: 1.4: 1.6$ in width ; club 4 -segmented, proximal first segment a little longer than broad, second and third quadrate and apical segment conical, about 1.5 times as long as broad.

Thorax rather flat, oblong, about 1.8 times as long as broad; mesoscutum closely reticulatesculptured throughout, covered with short silvery hairs ; scutellum transverse, glabrous ; metanotum very short, glabrous ; propodeum rather long with a fine central groove and punctures along the edge. Fore wings 3 times as long as broad ; stigmalis half as long as postmarginalis ; marginalis $1 / 4$ as long as postmarginalis. Hind wings 6.6 times as long as broad ; fringes $2 / 3$ of the greatest width of hind wing.

Metasoma elongate, lanceolate, about 2.4 times as long as broad ; first tergum longitudinally costate throughout ; second tergum about 1.4 times as long as broad, longitudinally striated on nearly basal $1 / 3$ in the median portion, gradually shortened toward the sides, elsewhere smooth and shining; following terga distinctly transverse.

Length : approx. $1.1 \mathrm{~mm}$. 
Type material : Holotype female (Type No. 2222-B, Kyushu Univ.), Mt. Hikosan, Fukuoka Pref., Kyushu, 4. vii. 1970 (M. Miyazaki). Paratypes: 1 female, Mt. Hikosan, Fukuoka Pref., Kyushu, 8. v. 1967 (M. Honda) ; 1 female, Kaidomura, Nagano Pref., Honshu, 22. vii. 1970 (K. Kanmiya) ; 2 females, Mt. Sudo (700 m), Kyungsangpuk-do, Korea, 9-12. vii. 1971 (K. Yamagishi) ; 1 female, Mt. Sudo (400 m), Kyungsangpuk-do, Korea, 17-18. vii. 1971 (K. Yamagishi).

Distribution: Japan (Kyushu, Hokkaido, Honshu) and Korea.

Platytelenomus elongatus Ryu, sp. n.

This new species is similar to Platytelenomus convexus, but differs from the latter in having the vertex rather flat as seen in front and tibiae yellowish brown. This is further characterized by the metasoma distinctly elongate, the first tergum longitudinally costate all over and the propodeum rather long with a fine central groove.

Female : Black. Antennae dark brown except for scape and pedicel which are yellowish brown. Legs yellowish brown with femora and tarsi infuscated.

Head transverse as seen from above, about 3.9 times as broad as its median length and slightly broader than thorax $(9: 8)$. Vertex very short with granular sculpture ; occiput notched. Frons and face rather flat, smooth and shining ; subocular space microscopically sculptured. Eyes with extremely short hairs, rather long, about 1.6 times as long as broad ; interocular distance nearly as long as eye. Antennae 11-segmented ; scape about 4 times as long as broad, about 2.8 times as long as pedicel; pedicel twice as long as broad, 1.3 times as long as first funicle segment ; first funicle segment slightly longer than broad, a little longer than second ; second a little longer than broad, about as long as third ; fourth and fifth rounded, nearly as long as broad ; club \$-segmented, proximal first segment quadrate, second and third slightly longer than broad and apical segment conical-ovate, about 1.4 times as long as broad.

Thorax 1.5 times as long as broad; mesoscutum distinctly flattened, with granular sculpture and covered with short, silvery hairs ; scutellum semicircular, smooth and shining ; metanotum strongly transverse, smooth and shining; propodeum rather long with a fine central groove and punctures along the edge. Fore wings about 4 times as long as broad ; postmarginalis about 3 times as long as marginalis ; stigmalis about 1.5 times as long as marginalis. Hind wings about 7 times as long as broad; fringes shorter that the width of hind wing.

Metasoma elongate, 2.1 times as long as broad ; first tergum transverse, with longitudinal costae all over; second tergum about 1.4 times as long as broad, longitudinally striated on basal half in the middle ; following terga distinctly transverse, smooth and shining.

Male : Antennae 12-segmented; scape about 3.7 times as long as pedicel; pedicel slightly shorter than first flagellar segment $(3: 4)$, slightly longer than broad $(2: 1.5)$; first flagellar segment about 1.5 times as long as broad, slightly shorter than second ; second to fourth subequal in length, each segment about twice as long as broad and longer than other flagellar segments; fifth to ninth subequal in length, slightly longer than broad ; apical segment conically elongate, about 3 times as long as broad. Otherwise like female.

Length : $1 \mathrm{~mm}$.

Type material: Holotype female (Type No. 2222-C, Kyushu Univ.), Mt. Haigamine, Hiroshima, Honshu, 27. vii. 1967 (H. Taguchi). Paratype male, same data as holotype.

Distribution: Japan (Honshu). 


\section{Selected References}

Kieffer, J. J., 1926. Scelionidae. Das Tierreich, 48 : 1-131.

Krombein, K. V., P. D. Hurd, Jr., D. R. Smith and B. D. Burks, 1979. Catalog of Hymenoptera in

America North of M exico, 1: 1-1198. (Scelionidae, by C. F. W. Muesebeck, pp. 1150-1171)

Masner, L., 1976. Revisionary notes and keys to world genera of Scelionidae (Hym., Proct.). Mem.

Ent. Soc. Canada, 9'7 : 1-87.

1980. Key to genera of Scelionidae of the Holarctic Region, with descriptions of new genera and species (Hym. : Proctotrupoidea). Mem. Ent. Soc. Canada, 113 : I-54.

Ryu, J. and Y. Hirashima, 1984. Taxonomic studies on the genus Trissolcus Ashmead of Japan and Korea (Hymenoptera, Scelionidae). J.Fac.Agr.,Kyushu Univ., 29 (1) : 35-58.

— and 1985. Taxonomic studies on the genus Telenomus Haliday of Japan and Korea (Hymenoptera, Scelionidae) Part I. Ibid., 30 (1) : 9-30.

- and - 1985. Ditto, Part II. Ibid., 30 (1) : 31-51.

Watanabe, C., 1954. Discovery of four new species of Telenominae, egg-parasites of Pentatomid and Plataspid bugs, in Shikoku, Japan (Hymenoptera : Proctotrupoidea). Trans. Shikoku Ent. Soc., 2 (2) : 17-26. 